\title{
Liquidity Demand When the Opportunity Cost of Money is a Perceived Total Return
}

\author{
Richard Dusansky ${ }^{1} \&$ Çağatay Koç ${ }^{2}$ \\ ${ }^{1}$ Department of Economics, University of Texas at Austin, Austin, TX, USA \\ ${ }^{2}$ Cornerstone Research, Washington, DC, USA \\ Correspondence: Richard Dusansky, Department of Economics, University of Texas at Austin, Austin, TX \\ 78712, USA. Tel: 1-512-471-3664. E-mail: dusansky@eco.utexas.edu
}

\author{
Received: May 4, $2012 \quad$ Accepted: August 20, $2012 \quad$ Online Published: November 27, 2012 \\ doi:10.5539/ijef.v5n1p1 URL: http://dx.doi.org/10.5539/ijef.v5n1p1
}

\begin{abstract}
Since total bond returns contain a potential capital gain (or loss) component, there can be a wide divergence between a bond's interest rate return and its perceived total return, depending on expectations about future interest rates and bond prices. It is possible for money demand to increase when bond interest rates are rising if one's perception is of a declining total return. We study the liquidity demand behavior of a group of bond fund portfolio managers, for whom the perceived total return is paramount, and find evidence of a positive relationship between bond interest rates, the standard proxy for the opportunity cost of money, and the demand for cash balances. While these empirical results contradict the traditional presumption of a negative relationship between the demand for money and a bond interest rate return, they make economic sense if the perceived total return on a bond is the true opportunity cost of holding cash balances.
\end{abstract}

Keywords: opportunity cost of money, money demand, liquidity demand, Keynesian speculative demand for money

\section{Introduction}

It is a common assumption that the relationship between an individual's demand for cash balances is inversely related to its opportunity cost, where the latter is represented by the current interest rate of a bond. A bond's interest return, however, is but one part of its total return. The other component is capital gain, or loss, realized at some future date, assuming the bond is not held to maturity. Since the total return is uncertain, the true opportunity cost of holding money is a "perceived" total return and is based on one's expectations about the future movement of bond prices. It is possible for there to be a wide divergence between a bond's current interest rate return and an individual's perception of its total return, and therefore possible for one's demand for money to be perversely increasing in the bond interest rate while decreasing in its expected (perceived) total return. (Note 1).

In this paper we study the behavior of a group of individuals for whom the perceived total bond return is paramount: portfolio managers of bond mutual funds. Empirical evidence of a significant positive relationship, or a statistically insignificant one, between cash holdings and a bond interest rate would suggest that some perceived total rate of return, rather than simply a bond's interest return, is the true opportunity cost of money. Since individual households that include bonds among their asset holdings may also exhibit this behavior as well, such a finding would also confirm the Cooley-LeRoy (1981) caution about assuming that the standard Keynesian assumption always holds.

\section{Data and Empirical Results}

Any attempt to study the behavior of fund managers over time confronts the problem of management style continuity. Fund managers often move from managing one fund portfolio to another within a given family of mutual funds or leave one mutual fund company to join another. Sometimes a mutual fund within a family of funds is merged with another, involving changes in investment style, objectives or fund leadership. Although one can find a plethora of data for a wide variety of mutual funds, it is a challenge to assemble a data set for which there is a high degree of confidence about fund management homogeneity over the time period under study. Our data set consists of Fidelity Investments bond funds. The data were culled from the monthly issues of Fidelity's 
Mutual Fund Guide, which provide detailed information on fund management, investment style, assets, etc. We study seventeen funds, eleven intermediate-term funds and six long-term funds, for which we have sixty monthly observations for the period April, 1991-March, 1996. While it is possible to extend the time period, the closing of weak performing bond funds and recombination of others would further reduce the number of funds under study.

Since our focus is on the liquidity (i.e., money) demand decisions of bond fund portfolio managers, we use a functional form motivated by Chordia (1996), who estimates the liquidity demands of mutual funds. It is important to note that bond funds usually are not fully invested. Cash balances are held for transactions purposes, to meet anticipated redemptions, and sometimes as a buffer for unanticipated redemptions. In addition, cash balances are often held for speculative purposes, influenced by expectations about bond price movements. Our regression formulation is given by

$$
L I Q_{t}=\alpha_{0}+\alpha_{1} \text { LNASST }_{t}+\alpha_{2} \text { INFLOWS }_{t}+\alpha_{3} \text { LNINTRATE }_{t}+\varepsilon_{t}
$$

where LIQ represents cash holdings, stated as a percentage of total net assets in the previous month, LNASST is the logarithm of total net assets, INFLOWS is a fund's net inflow during the month, stated as a percentage of its total net assets in the previous month and LNINTRATE is the logarithm of the bond interest rate. (Note 2). Cash holdings LIQ are taken to be fund assets not invested. i.e., money held as cash or in cash equivalents. Total net assets are included to capture the transactions demand impact on cash holdings, while the bond interest rate is included to capture the speculative demand motive. Net inflows are included as an adjustment variable. It is computed by subtracting beginning of month total net assets, corrected for the monthly returns, net of management fees and the expense ratio, from the end of month total assets. The inclusion of net inflows allows us to account for money demand changes that are due to monthly flows, as separate from the transactions demand impact of total assets on cash holdings.

We expect the sign of the total net assets variable to be positive since an increase in a fund's asset size would increase anticipated redemptions and may increase the cash holdings used to buffer against unanticipated redemptions. We regard the expected sign of the bond interest rate variable to be an open question. We purposely focus on a single bond interest rate in our formulation in order to avoid the Cooley-LeRoy (1981) critique that "one reason why most studies of money demand include more than one interest rate is that only by so doing does the feasible parameter space become sufficiently large that researchers can find a specification that confirms their prior belief of a significant and negative interest rate effect on money demand." (Note 3). If we estimate a statistically significant negative coefficient on the bond interest rate, the finding will not be easily dismissible on these grounds.

Although a single bond interest rate appears in the regressions, the particular interest rate used depends on the fund class. The intermediate-term bond funds have dollar weighted average maturities of three to nine years; the most relevant bench-mark interest rate is that of the 7 Year Treasury Note. Long-term bond funds have double digit dollar weighted average maturities of up to thirty years; the most relevant bench-mark interest rate for the time period under study is the 30 Year Treasury Bond. Consequently, the regression for the group of intermediate-term bond funds employs the 7 Year T-Note rate while the regression for the group of long-term bond funds employs the 30 Year T-Bond rate. (Note 4). We use the interest rate for the last week of each month.

We start by examining the stationarity properties of the variables that are in the regressions. We employ the augmented Dickey-Fuller (ADF) unit root test to test the null hypothesis that a variable is non-stationary (i.e., has a unit root) and also carry out Dickey-Fuller/Generalized Least Squares (DF/GLS) unit root tests in order to confirm the ADF test results, since the latter test exhibits better overall performance for small samples. Table 1 presents the results of the unit root tests for our variables. (Note 5). The null hypothesis of unit root can be rejected at the 5\% significance level for the logarithm of the bond interest rate variables; these variables are stationary. However, for the remaining independent variables Inflows and Log of Total Net Assets, as well as for the dependent Liquidity variable, the null hypothesis of unit root is not rejected. This is the case for all conventional levels and for each bond fund group. 
Table 1. Unit Root Test Statistics

\begin{tabular}{|c|c|c|}
\hline & $\mathrm{ADF}$ & $\mathrm{DF} / \mathrm{GLS}$ \\
\hline \multicolumn{3}{|c|}{ Intermediate-Term Bond Funds } \\
\hline Liquidity & -1.763 & -1.395 \\
\hline Log Total Net Assets & -2.760 & -1.437 \\
\hline Inflows & -2.244 & -0.486 \\
\hline \multicolumn{3}{|l|}{ Long-Term Bond Funds } \\
\hline Liquidity & -2.093 & 0.454 \\
\hline Log Total Net Assets & -1.537 & -1.120 \\
\hline Inflows & -2.360 & 0.129 \\
\hline \multicolumn{3}{|l|}{ Interest Rates } \\
\hline Log 7 Year T-Note & $-2.944 * *$ & $-1.941 *$ \\
\hline Log 30 Year T-Bond & $-2.913 * *$ & $-1.993 * *$ \\
\hline Log 30 Day T-Bill & -2.528 & $-2.202 * *$ \\
\hline
\end{tabular}

Single asterisk indicates statistical significance at $10 \%$; double asterisk at $5 \%$. Since the Log of Total Net Assets for the Intermediate-Term bond funds exhibits an increasing trend, we use the test equation that includes both constant and trend.

Whether we analyze the intermediate-term bond funds or the long-term bond funds, the dependent variable in our regression specification in (1) is non-stationary. For both bond fund money demand regressions, the set of independent variables includes both non-stationary variables (Inflows, Log of Total Net Assets) and a stationary variable (Log of Interest Rate). Park and Phillips (1989) show that if the dependent variable $(y)$ of a linear regression specification is non-stationary and if the set of regressors include both non-stationary $(x)$ and stationary ( $\mathrm{z}$ ) variables, then, provided that $\mathrm{y}$ and $\mathrm{x}$ are cointegrated, the least squares estimates of the parameters of such a specification are consistent. We next examine whether Liquidity, Log of Total Net Assets and Inflows are cointegrated for each bond fund.

The results of the cointegration tests appear in Table 2. We report two test statistics: the Johansen trace statistic and the Johansen maximum eigenvalue statistic. The null hypothesis for the trace statistic is that there are no more than $r$ cointegrating equations and the test accepts as the number of cointegrating equations the first $r$ for which the null hypothesis is not rejected. The maximum eigenvalue statistic assumes some given $r$ cointegrating equations under the null and tests this against the alternative of $r+1$ cointegrating equations. For the long-term bond funds, both tests indicate that there is a single cointegrating equation among Liquidity, Log of Total Net Assets and Inflows. For the intermediate-term bond funds, the tests indicate that there are two cointegrating equations among these variables. We also employ the Schwarz Bayesian information criterion to determine the number of cointegrating equations for each of the bond funds. Gonzalo and Pitarakis (1998) and Aznar and Santos (2002) show that choosing the number of cointegration equations that minimizes the Schwarz Bayesian information criterion provides a consistent estimate of them. The Schwarz Bayesian information criterion indicates that there are two cointegrating equations among these variables for the intermediate-term funds and confirms that there is one cointegration equation among these variables for the long-term funds. As a consequence of the above results, using Park and Phillips' (1989) findings, we conclude that the parameter estimates resulting from our least squares estimation of (1) are statistically consistent.

Table 2. Cointegration Test Statistics

\begin{tabular}{llll}
\hline & Number & Trace & Maximum \\
& Cointegrating & Statistic & Eigenvalue \\
& Equations & & $41.71^{* *}$ \\
& 0 & $66.35^{* *}$ & $18.84^{* *}$ \\
\hline Intermediate-Term Funds & 1 & $24.64^{* *}$ & $5.80^{*}$ \\
\hline Long-Term Funds & 2 & $5.80^{*}$ & $25.33^{* *}$ \\
& 0 & $36.11^{* *}$ & 10.39 \\
\hline
\end{tabular}

Single asterisk indicates statistical significance at $5 \%$; double asterisk at $1 \%$. 
The results are in Table 3. Two sets of regression results are reported, the first for the group of intermediate-term bond funds and the second for the group of long-term bond funds. Recognizing the problems associated with serial correlation in time series data, we employ the Newey-West (1987) variance estimator that produces consistent estimates for the variance of the least squares estimator in the presence of autocorrelation. TheNewey-West variance estimator handles autocorrelation up to and including a pre-determined lag. Thus, it assumes that any autocorrelation at lags greater than the pre-determined maximum lag value can be ignored. We choose the maximum lag value using the lag selection formula in Newey and West (1994). (Note 6).

The estimated coefficient for the total net assets variable is positive and statistically significant for the group of intermediate-term funds. The estimated coefficient on the bond interest rate variable is positive and statistically significant in each of the two regressions. For every one percent increase in the bond interest rate, intermediate term funds increase the percentage of total net assets held in money by 24.97 points, whereas the increase for long-term funds is 14.66 points. The corresponding elasticities are 3.52 and 2.71 , respectively. (Note 7 ). The estimated coefficient of the net inflows variable is positive in each regression and statistically significant for the group of long-term bond funds.

The results depicted in Table 3 constitute the basic empirical finding of this paper. However, there are two extensions worthy of consideration. The first is to introduce a second interest rate variable, as a measure of the short-term return to holding money balances. Managers of the Fidelity bond funds under study are generally not free to pursue other assets, but they can (and do) hold monetary balances as part of their portfolios. One can conjecture that the degree to which they hold money, and indeed the degree to which they reduce bond holdings in favor of higher monetary balances, may well be tempered by the short-term interest rate on money balances. While the dominant motivation for reducing bond holdings in response to bond interest rate increases is avoidance of capital loss, the degree to which money is substituted for bonds, on the margin, may be influenced by the short-term money interest rate. We therefore introduce the log of the 30-day T-bill rate as an additional independent variable, in order to account for this potential phenomenon and re-estimate the two equations. Since this variable is stationary, by the preceding cointegration test analysis, we can estimate this new set of regressions with the least squares method as well. The results are depicted in Table 4.

Table 3. Bond Fund Money Demand: Base Formulation

\begin{tabular}{lll}
\hline & Intermediate-Term Funds & Long-Term Funds \\
\hline Intercept & -163.09 & -35.39 \\
& $(38.05)^{* *}$ & $(33.57)$ \\
\hline Log Total Net Assets & 13.42 & 1.40 \\
& $(3.22)^{* *}$ & $(3.25)$ \\
\hline Inflows & 0.23 & 0.51 \\
& $(0.16)$ & $(0.12)^{* *}$ \\
\hline Log 7 Year T-Note & 24.97 & \\
\hline Log 30 Year T-Bond & $(4.91)^{* *}$ & 14.66 \\
& & $(4.19)^{* *}$ \\
\hline R-Square & & 0.52 \\
\hline
\end{tabular}

Newey-West standard errors are in parentheses. Double asterisk indicates statistical significance at $5 \%$; triple asterisk at $1 \%$. Number of observations is 59 . 
Table 4. Extension of Base Formulation to Two Interest Rates

\begin{tabular}{lll}
\hline & Intermediate-Term Funds & Long-Term Funds \\
\hline Intercept & -128.38 & -88.86 \\
& $(33.68)^{* * *}$ & $(96.06)$ \\
\hline Log Total Net Assets & 10.64 & 7.02 \\
& $(2.71)^{* * *}$ & $(9.72)$ \\
\hline Inflows & 0.13 & 0.49 \\
& $(0.15)$ & $(0.13)^{* * *}$ \\
\hline Log 30 Day T-Bill & 4.42 & 1.90 \\
& $(2.14)^{* *}$ & $(2.96)$ \\
\hline Log 7 Year T-Note & 16.74 & \\
& $(5.93)^{* * *}$ & 16.12 \\
\hline Log 30 Year T-Bond & & $(5.54)^{* * *}$ \\
\hline R-Square & 0.66 & 0.52 \\
\hline
\end{tabular}

Newey-West standard errors are in parentheses. Double asterisk indicates statistical significance at 5\%; triple asterisk at $1 \%$. Number of observations is 59 .

Two sets of regression results are again reported. Overall, the pattern is similar to that in Table 3. With regard to the added variable, in each regression the estimated coefficient on the 30-day T-bill rate is positive; it is statistically significant for the intermediate-term bond funds. The addition of the short-term interest rate is important. Without it, the estimated coefficients on the respective target bond interest rates may spuriously mask their effect. In Table 3, the estimated effect of a one percent increase in the bond interest rate on the monetary holdings of intermediate-term bond funds is 24.97 points as compared to 14.66 for long-term bond funds, with corresponding elasticities of 3.52 and 2.71, respectively. In Table 4, after separating out the effects of the short-term money interest rate, these estimates nearly converge to a common value of about 16 , with corresponding elasticities of 2.36 and 2.99. It is noteworthy that the estimated coefficients for the target interest rate variable, the 7 Year T-Note for the intermediate-term bond funds and the 30 Year T-Bond for the long-term bond funds, remain positive and statistically significant. Increases in bond interest rates are associated with increases in the holding of money balances.

The second extension is to account for the possibility that expectations are influenced by the degree of interest rate changes, not simply an alteration in their levels. We capture this by adding the lagged interest rate, using a lag of one. This is a general way of accounting for interest rate changes. The results are depicted in Table 5. Once again, the overall results are similar to the basic results in Table 3 .

Table 5. Extension of Base Formulation to Lagged Interest Rates

\begin{tabular}{lll}
\hline & Intermediate-Term Funds & Long-Term Funds \\
\hline Intercept & -168.58 & -36.80 \\
& $(32.44)^{* * *}$ & $(30.72)$ \\
\hline Log Total Net Assets & 13.69 & 1.38 \\
& $(2.69)^{* * *}$ & $(3.03)$ \\
\hline Inflows & 0.09 & 0.45 \\
& $(0.13)$ & $(0.13)^{* * *}$ \\
\hline Log 7 Year T-Note & 6.20 & \\
& $(5.75)$ & \\
\hline Log 7 Year T-Note Lagged & 20.38 & \\
& $(7.61)^{* * *}$ & 2.96 \\
\hline Log 30 Year T-Bond & & $(8.39)$ \\
\hline Log 30 Year T-Bond Lagged & & 12.50 \\
& & $(5.80)^{* *}$ \\
\hline R-Square & 0.66 & 0.54 \\
\hline
\end{tabular}

Newey-West standard errors are in parentheses. Double asterisk indicates statistical significance at 5\%; triple asterisk at $1 \%$. Number of observations is 59 . 
The empirical results reported above should not be considered perverse. Bond interest rate increases may lead to expectation of a capital loss, thus affecting the total return on bond holdings (i.e., the perceived opportunity cost of money), prompting bond fund portfolio managers to "lighten-up" on their bond holdings and to increase monetary balances.

Starting in the 1950s and progressing steadily in intensity since then, the role of financial intermediaries in general and of mutual funds in particular has grown enormously. Vast amounts of funds are now handled by bond portfolio managers and other institutional fiduciaries that specialize in fixed income assets. Speculation in bonds and money - where speculation is understood in the conservative sense of fiduciary responsibility to avoid capital loss and preserve capital - plays a large role in contemporary financial activity. We take the empirical findings above as suggestive of the importance of these forces.

\section{Summary and Conclusions}

The true opportunity cost of holding money is the total return on some bond, which contains an uncertain capital gain (or loss) component, not simply its interest rate return. There can be a divergence between the interest return and one's perception of the total return, resulting in a money demand response that is upward sloping with regard to a bond's interest rate return while being downward sloping with respect to the perceived total return. We study the liquidity demand behavior of a group of bond fund portfolio managers and find evidence of a positive relationship between bond interest rates and the demand for cash balances. For them, the Keynesian speculative component of money demand is sensitive to expectations of bond price movements, so that changes in interest rates can produce what may appear to be "perverse" empirical results. However, if the focus is on the perceived total bond return rather than its interest rate return, then the results make economic sense.

The amount of financial assets held by bond funds has grown enormously in recent decades, along with the direct holdings of bonds by consumers who include them among their asset holdings. The sample of bond funds analyzed above is small, in order to ensure continuity of portfolio management style. Our findings are therefore only suggestive. However, should they hold more generally, policy makers who rely on the traditional assumption of a negative relationship between money demand and a bond interest rate may need to proceed with caution, especially when there is heightened uncertainty about future interest rates and bond prices.

\section{References}

Aznar, A., \& M. Santos. (2002). Selecting the Rank of the Cointegration Space and the Form of the Intercept Using an Information Criterion. Econometric Theory, 18, 926-947. http://dx.doi.org/10.1017/S0266466602184064

Chordia, T. (1996). The Structure of Mutual Fund Charges, Journal of Financial Economics. 41, 3-39. http://dx.doi.org/10.1016/0304-405X(95)00856-A

Cooley, T. F., \& S. F. Leroy. (1981). Identification and Estimation of Money Demand. American Economic Review, 71, 825-844.

Dusansky, R., \& C. Koc. (2009). Demand for Cash Balances in a Cashless Economy. International Journal of Economic Theory, 15(3), 301-313. http://dx.doi.org/10.1111/j.1742-7363.2009.00111.x

Fidelity Investments. (1996). Mutual Fund Guide, April 1991-March.

Goldfeld, S. M., \& Sickel, D. E. (1990). The Demand for Money. Handbook of Monetary Economics, 1, edited by B. M. Friedman and F. H. Hahn, Elseiver Science Publishers B. V., 299-356. http://dx.doi.org/10.1016/S1573-4498(05)80011-6

Gonzalo, J., \& J. Y. Pitarakis. (1998). Specification via Model Selection in Vector Error-Correction Models. Economics Letters, 60, 321-328. http://dx.doi.org/10.1016/S0165-1765(98)00129-3

Llaidler, D. E. W. (1993). The Demand for Money. 4th edition, Harper Collins, New York.

Newey, W., \& K. West. (1987). A Simple, Positive Semi-Definite, Heteroskedasticity and Autocorrelation Consistent Covariance Matrix. Econometrica, 55, 703-708. http://dx.doi.org/10.2307/1913610

Newey, W., \& K. West. (1994). Automatic Lag Selection in Covariance Matrix Estimation. Review of Economic Studies, 61, 631-653. http://dx.doi.org/10.2307/2297912

Ng, S., \& P. Perron. (1995). Unit Root Tests in ARMA Models with Data-Dependent Methods for the Selection of the Truncation Lag. Journal of the American Statistical Association, 90, 268-281. http://dx.doi.org/10.1080/01621459.1995.10476510

Park, J. Y., \& P. C. B. Phillips. (1989). Statistical Inference in Regressions with Integrated Processes: Part 2. 
Econometric Theory, 5, 95-131. http://dx.doi.org/10.1017/S0266466600012287

Schwert, G. W. (1989). Tests for Unit Roots: A Monte Carlo Investigation. Journal of Business and Economic Statistics, 7, 147-160.

\section{Notes}

Note 1 . The expected return can be negative if one expects a capital loss that outweighs the bond interest return.

Note 2. Theoretical modeling of inter-temporal uncertainty indicates that the current interest rate, rather than some proxy for its future expected value, is the proper right hand side variable. Expectations of future interest rates and bond prices are taken to be based on current period values. When expected utility is maximized, the derived demand function for money has only current period variables as its arguments.

Note 3. Cooley and LeRoy (1981), p. 835.

Note 4. In recent years, the 10 Year Treasury Bond has become paramount. However, for the period under study, the 30 Year Treasury Bond was the "bellweather."

Note 5. The lag length in the unit root test equations is chosen using the Ng-Perron (1995) sequential procedure for testing the significance of the lag coefficients in the test equations. Specifically, one starts the unit root tests with a maximum lag length $\mathrm{k}$. As suggested by Schwert $(1989)$, $\mathrm{k}$ is determined by $\mathrm{k}=\left[12(\mathrm{~T} / 100)^{1 / 4}\right]$, where $[\mathrm{x}]$ denotes the integer part of $\mathrm{x}$ and $\mathrm{T}$ is the number of observations. If the absolute value of the t-statistic for testing the significance of the last lagged difference in the test equation is significant at the .10 level, then the lag length in the test equation is k. Otherwise, one reduces the lag length by one and repeats the same process.

Note 6 . The number of Newey-West lags to use in calculating the standard errors is given by $\left[4(T / 100)^{2 / 9}\right]$ where $[\mathrm{x}]$ denotes the integer part of $\mathrm{x}$ and $\mathrm{T}$ is the number of observations.

Note 7 . Here we divide the interest rate coefficients by the sample means of the liquidity ratios. 